\title{
THE REORGANIZATION OF CORPORATIONS IN GERMANY
}

\author{
JOSEPH L. WEINER
}

Comparison between the reorganization practice of England and of America has become common, and many desirable innovations in our present practice have been the fruit of it. A comparison with reorganization of corporations in Germany has likewise many things to offer. A chief source of interest lies, probably, in the fact that the reorganized companies are industrial corporations, whereas the reorganization of industrial corporations in America has been slighted by writers in favor of the more spectacular and rather more uniform railroad reorganization. Of more general interest is the striking parallel that exists at bottom between reorganization here and there, the similarity of the problems to be met, the similarity of the solutions, of the complaints made by objectors to reorganization plans, and even of judicial decisions. Lastly, the subject should prove interesting to that part of the public, rapidly growing, which has contact with German securities. The present and prospective position of the United States as a capital market, with Germany one of the most prominent bidders at that market, creates the impression that the number of American holders of such securities will be very large.

\section{THE FACT BASIS}

The reader who is familiar with American reorganizations requires a few preliminary facts lest he draw conclusions rashly. One such fact has already been noted, namely, that this discussion deals with industrial enterprises, and almost never with public utility corporations. In making comparisons, therefore, it is important to exclude notions based solely on railroad receivership and reorganization, our most familiar exemplar.

If we take the year 1912, a sort of intermediate date, the following picture of German stock corporations ${ }^{1}$ presents itself: a total of about 5,400 ; a total capitalization of about 18 billion

I The corporation laws of Germany, like those of many other countries, recognize two distinct forms of limited liability companies. In Germany these are called the Aktiengesellschaft and the Gesellschaft mit beschracnkter Haftung. The latter was designed for that type of enterprise which was smaller in scope and which did not propose to finance itself by solling securities to the general public. The present discussion is limited to the reorganization of the Aktiengesellschaft, although the reorganization of the Gesellschaft mit beschraenkter Haftung presents only slight variations. 
marks, almost all in one class of securities-hardly any preferred stock. These companies have about 413 billions of bonds outstanding, of which approximately half are secured by mortgage. The chief thing to note about stock, besides the slight amount of preferred stock, is that every share is entitled to one vote, and with rare exceptions none is entitled to more than one vote.

Of more importance is the fact that in the promotion of corporations in Germany the severe regulatory rules of the Corporation Law, requiring an independent audit of property contributed for stock, and placing responsibility on a large group of participants for fraudulent promotions, and the even severer rules that regulate the admission of securities to the exchanges, - a total effect which may best be described as a different system of promotion-have largely abolished stock-watering. As a consequence an equity in the property is established which has secured creditors to a degree exceeding that in this country, and which partially accounts for the fact that most reorganizations in Germany are stockholders' reorganizations.

\section{THE PROCEDURE IN GENERAL}

The business procedure in the course of reorganization parallels that in America, with the modifications made necessary by a different system of jurisprudence. The usual committees are often found, deposits are made (though rarely of stock-the reasons for depositing bonds will appear later), the minority and majority interests clash, and compromises are effected. A good deal of the administrative side of our reorganizations can be dispensed with, however, because of the legal devices used to enforce a reorganization plan. In the first place, the whole procedure is usually accomplished without the aid of a court. Until 1924 there was nothing in Germany corresponding to the equity receivership which is frequently the first step in the reorganizations of corporations here. Hence, to prevent creditors from asserting their claims, private efforts are necessary to leep them in line. Sometimes the pressure of banks will do this, sometimes nothing will. This is a second factor which makes the German reorganization preeminently a stockholders' reorganization. Curiously enough, this lack of judicial machinery for coercing general creditors, or for cing them to postpone their actions for a time, is not true regarding bonds. By a statute of 1899 elaborate rules were established for calling meetings of bondholders, appointing a representative, voting on surrender of property, reduction of interest, and on most of the other sacrifices usually sought of bondholders in reorganization.

With the absence of receivership there is also an absence of the foreclosure and the transfer to a new company, which is typical in our procedure. As in England, once the chief steps 
are decided on the rest is a matter of voting. This disposes efficaciously enough of the stocks and bonds, but leaves the general creditors in an extraordinarily favorable position. With these preliminary facts in mind we can proceed to study the types of reorganization in greater detail. ${ }^{2}$

\section{STOCKHOLDERS' REORGANIZATIONS}

The great majority of the reorganizations in Germany are, as was mentioned before, stockholder's' reorganizations, $i$. $e$., the rights of creditors are not affected. The balance sheet shows a considerable deficit, the stock is selling below par, and credit is bad. To remedy this situation, and to provide new money, it is decided to reorganize.

At the next annual meeting, or at a special meeting called for the purpose, the management proposes a plan of reorganization. The proposal may take the following forms:

1. If new money is not needed, a simple reduction of the capital stock may be proposed. ${ }^{3}$ This would be the case if the company had, for example, suffered a fire loss and had decided that dividends should be paid while the loss was being amortized.

2 The unusual publicity required by German corporation law has resulted in extremely able comment in the commercial part of the daily newspapars. Two of them, the FrankFurTer ZeITUNG and the BERLINER TAGEBLATT, enjoy an enviable reputation and are a mine of information. The financial newspapers such as the BERLINER BOERSENZEITUNG naturally carry such information and are always useful. 'Some of the economic journals make a practice of balance sheet analysis; the best known are DER DEUTSCHE OEkonomist and Plutus (which has since changed into Magazin der WIRTSCHAFT)., DER DEUTSChe VolKSWIRT carries less material of this kind, but what it has is good. Still another reliable source is WIrTscharTsDIENST, published by the Weltwirtschaftsarchiv at Hamburg. The annual volumes of Saling's BoERSENPAPIERE and the HANDBUCH DER DEUTSCHEN AKTIENGESELLSCHAFTEN compare favorably with Poor's and MOODY's. ManNheimer, Die Sanierung (1924) is a good elementary survey, and the chapters on reorganization in SCHMALENBACH, FinANzIarungen (3d ed. 1922) and Wolf and Birkenbihe, Die Praxis der Finanzigrung (5th ed. 1923) are interesting.

3 The statutory requirements for reducing or increasing the capital stock are as follows: the resolution requires a majority equal to three-fourths of the voting capital. If several classes of stock have been issued, the resolution requires the separate approval of each class, besides the approval by joint resolution (Commercial Code, $\S 288$ ). The usual method for reductions is to require the necessary proportion of shares to be handed in for cancellation. Sometimes the nominal amount of each share is reduced; in a few cases both methods were combined. The difficulty with reducing the nominal amount was the provision of sec. 180 that bearer shares must have a par value of at least 1000 marks, which was the usual par value for which they were issued (since 1923 only 100 mark shares are required). Shares which are not presented may be declared void by the company; an equivalent number of new shares is to be issued and sold by the company, the proceeds to go to the owners of the old shares. 
Or, again, it may happen in a closely held corporation, such as the Westinghouse Elektrizitaetsgesellschaft, where the only object was to remove the deficit from the books and the balance sheet.: Occasionally, one finds a reduction of capital stock accompanied by a sacrifice on the part of general creditors or bondholders; this would indicate that the stockholders could not be depended upon to contribute new money. But such cases are rare. ${ }^{5}$ In general the reorganization by a mere reduction of capital stock plays an unimportant role. ${ }^{\circ}$

2. Another simple expedient is to ask for payment of a specified amount per share and to confer preferred rights upon those shares upon which payment is made. ${ }^{7}$ This would indicate again a situation which was not urgent, since such payments would be totally inadequate if a company were in serious difficulties. For that reason, this expedient was rarely resorted to, ${ }^{8}$ especially since preferred stock was in bad repute, at least before the war.

\& Resolution in 1907. This is one of the distant echoes of the famous Westinghouse reorganization. The same situation is present in the Zweibruecker Exportbrauerei A. G. reduction of 200:1 in 1907. Schmalenbach says that a case like this looks like an attempt to freeze out the small stockholder, but the fact is that the entire capital stock was owned by the Brauerei Loewenberg in Zweibruecken.

5 The Aquila A. G. was such a case. So were the Pommersbanl: and the Preussenbank discussed infra pages 760, 761 .

- Sec. 240 of the Commercial Code requires the directors to call a meeting of the shareholders whenever it appears in the course of setting up an annual or interim balance sheet that half of the nominal capital is lost. This the directors are naturally loath to do. Hence, when that stage is about to be reached, they prefer to suggest a reduction of capital stocls, pointing to the possibility of paying dividends, improving the market price, and the like. Schmalenbach is of the opinion that most "pure" reorganizations, i.e., where the only change is a reduction of the capital stock, are due to this, citing the Duesseldorf-Ratinger Roehrentesselfabrilk reduction of $5: 3$ in 1907 .

I The authority for this is spelled out of sec. 262: "For the covering of deficits which appear in the balance sheet a reserve fund is to be created. To this fund are to be credited. . . . (3) The amount of payments which are made by shareholders for granting of preferred rights on their shares. . . " It was contended formerly, especially by Staub in the earlier editions of his COMMENTARY, that unanimous consent was required for granting of such rights on old shares, but this is nov universally rejected; the regular majority for amending the articles of incorporation suffices.

8 The Vereinigte Eisenbahn und Betriebsgesellschaft in Berlin, with a capital of 5,000,000 marks, voted at an extraordinary meeting held on September 30, 1902, to ask for payment of 300 marks per share. The shares on which payment was made were to be 5 per cent cumulative preferred, and to participate in further earnings equally according to par values. The shares were also to be preferred and participating on liquidation. A shareholder pointed out at the meeting the great damage to those who could not pay. The chairman answered that the new money was necessary for the successful development of the company and that to assure it 
3. The typical proposal is a reduction of capital stock with a proviso that those who pay a specified amount are free in whole or in part from the reduction. Usually those who pay also have their shares converted into preferred stock. The practice varies. There may be a provision that upon certain conditions, usually the payment of dividends for a number of years, the preferred rights shall cease.

This favorite form of reorganization ${ }^{\circ}$ received a severe blow in a leading decision of the Federal Supreme Court. The Maerkisch-Westfaelische Bergwerksverein, a lead and zinc mining and smelting company organized in 1854, suffered severe losses from a continued disruption of its market, beginning in 1896. These losses reacted directly on the market price of its shares, which declined from well above par in 1896 to 56 per cent in 1901, the time of the proposed reorganization, having passed through a low-water mark of 30 per cent.

The reorganization plan was as follows: Five old shares (par value 600 marks per share), upon payment of 800 marks in cash, were to be exchanged for two new preferred shares of 1000 marks each. The shareholders who did not exercise this privilege were to have their holdings reduced in the ratio of four to one. A resolution to this effect was attacked in the courts and came to the Federal Supreme Court, which declared it illegal.10

The court based its decision on the following considerations. Section 211 of the Commercial Code limits the duty of a shareholder to pay for this share to the nominal amount of the share. This forbids further assessment. Pressure to pay a further

the greatest advantages must be offered; other suggestions had been considered and found not feasible.

Payment was made on 4598 shares out of 5000. Two years later the company voted to grant the preferred rights to the remaining common stock upon payment of 400 marks on each share of common. Payment was made on 224 shares, leaving a total of 178 common shares. See PASsow, Artingaesellschaft (2d ed. 1922) 205-6. The Hoextersche Portland Zementfabrik reorganization in 1902 is another example of reorganization by payment against preferred rights.

$\theta$ The literature on this form of reorganization is copious, but almost all of it is legal. A discussion is certain to be found in all of the commentaries on the Commercial Code under sec. 288 or 290, e.g., STAUB-PINNER, DUeringer-Hachendurg, Lehmanis-Ring, MaKower. Special volumes on the subject were written by LeIST, SANIERUNG DER AKTIENGESELLSCHAFT (1905); Brantl, Die Sanierung Von AKTIEngesellschaften (1908); Fischer, Das Sanierungsproblem (1911); Zadek, Die Sanieruna (1916); Merer, Die SANierung (1918). The periodical literature can be found in any of these books.

${ }^{10}$ Entscheidungen des Reichsgerichts in Zwilsachen (cited as R. G.) 50, 52. A lower court opinion to the same effect is reported in Deutsche JURISTEN ZeITUNG (1902) 153. 
assessment might be exerted by the corporation's refusing to recognize a shareholder who declined to pay. This would clearly be illegal; but pressure might also be exerted indirectly by favoring the shareholders who pay, more than is justified by the new money. Such compulsion is equally illegal. This was the situation here; the shareholders who pay "surrender five old shares totaling 3000 marks. In exchange they receive 2000 marks in new shares less the 800 marks cash which they pay, or a total of 1200 marks. Their sacrifice on the old shares is therefore sixty per cent. But the shareholders who do not pay are asked to sacrifice seventy-five per cent. Justice requires that the reduction be the same for all.

This decision is the Boyd case 11 of German reorganization, and its critics use, in the main, arguments familiar in the Boyd case discussions..$^{12}$ According to the court below, ${ }^{13}$ equality means equality of opportunity. Since it was open to all shareholders to participate on the same terms, there was no discrimination as against any, and aside from discrimination there could be no question of compulsion. This familiar doctrine requires no further elucidation. Another criticism offered resembled the argument in the Boyd case: no reorganization would succeed without some kind of compulsion and hence the court "required the impossible." A few dissenters raised the question of "upsetting well-known and long acted-on arrangements."

Still another criticism is from the viewpoint of what might be called the equity of the situation. It contends that the hazard involved in the payment of new money may be totally disproportionate to the advantage derived from the more favorable treatment of the payer's old shares. Not all reorganizations are successful; the payers of new money deserve some kind of compensation.

The former objections were carefully considered and found wanting by the Federal Supreme Court. The latter are not so easily disposed of. It is pointed out by Schmalenbach that the equality required by the court is short-sighted. It would amount to real equality only where the reduction brought the market

11 Northern Pacific Ry. v. Boyld, 228 U. S. 482, 33 Sup. Ct. 554 (1913). Discussions of this case are legion; to those cited in Weiner, Conflicting Functions of the Upset Price in a Corporate Reorganization (1927) 27 Cor L. REv. 132, there have since been added Swaine, Rcorganization of Corporations: Certain Developments of the Last Decade (1927) 27 Coc. L. Rev. 901; Bonbright and Bergerman, Tuo Rizal Theories of the Priority Rights of Security Holders in a Corporate Reorganization (192S) 28 COL. L. REv. 127.

12 No attempt is made to give the source of any of these arguments. The curious reader can find them in the literature cited supra notes 2 and 9.

${ }^{13}$ Rechtsprechung der Oberlandesgorichte, 4,230. Also reported in Deutsche JuRisten Zeitung (1902) 179. 
price of the shares to par. If the market price of the shares before the reduction is 67 , then a reduction of $4: 3$ is not the same as a payment of 25 ; it is in fact a disadvantage to the payer, whereas a reduction of $2: 1$, or payment of 50 , is a disadvantage to the non-payer. A similar criticism uses the same technique but employs as its point of approach the "intrinsic" (book) value of the shares.

The court adverts to some of these latter points in a later decision, ${ }^{14}$ where it makes its position more specific. That the future may not show success, says the court, is not of judicial interest. If that were not so, a court would be helpless in the face of any imposition on the minority stockholder. It must assume that the management has measured the adequacy of the terms proposed to assure future success; beyond this it cannot go. ${ }^{15}$ As to the equality required, the court disclaims the suggestion that in a proper case it might look beyond the ratios of par values of the securities to the ratio of their real values. ${ }^{10}$ In determining the ratio the par value only of the stock will be considered. The reasons are largely that there is no other adequate measure; the court will assume that the company is seeking payment sufficient to restore the stock to its par value; the same ratio must be taken for non-payers.

Other writers have called attention to the fact that the court's decision sanctions the change of the stock from common to preferred. There is no doubt that the granting of preferred rights introduces an incalculable factor in determining the validity of any ratio. This is especially so since the preferred rights are usually both cumulative and participating. The court justified the granting of preferred rights to the paying shareholders on the ground that the Commercial Code sanctions the granting of preferred rights in return for the payment of an assessment. But here the court is clearly inconsistent. If it regards the new money as a payment for the difference in amount of shareholding between paying and non-paying stockholders, as its notion of ratio equality compels it to, no new money remains to be counted as payment for preferred rights. If, on the other hand, some part of this money is to be attributed to the granting of preferred rights, the courts' fixed ratio is destroyed. ${ }^{17}$

14 R. G. 80,81 .

15 The court probably meant that since the reorganizers told the paying shareholders that the proposed measures meant future success, they would be estopped from telling the contrary to non-payers.

16 This was especially the contention of Leist, who said that the court would prohibit an excessive reduction even though the parity were otherwise maintained.

17 A similar situation occurs in the United States where common stock is given with a sale of bonds or preferred stock, and the court must decide whether any value was given for the common. This difficulty persists even 
The legality of granting preferred rights on all the stock given to those who pay the assessment is usually defended on the ground that this is an issue of preferred for which the old common is accepted at an agreed price. But although this practice is almost universal, the court refused to sanction the doctrine when presented to it in balder form. This case ${ }^{18}$ involved an issue of preferred with the proviso that an old shareholder who subscribed for one share of the preferred would have preferred rights on two of his old shares. The court held this plan void. Yet apparently the same result could have been reached by the issuance of a preferred share of 3000 marks in exchange for two old shares and 1000 marks in cash.

Despite the fears of reorganizers that the court's decision required the impossible, it soon developed that reorganization could be carried out without revolutionary departures from the norm to which industry was accustomed. The necessary changes can readily be seen in the case of the Helios Elektrizitaetsgesellschaft. ${ }^{19}$ The original reorganization plan of this company was drawn about the same time as that of the MI.-W. Bergwerksverein. It offered to stockholders the opportunity of exchanging two out of every five shares, of 1000 marks each, for two new preferred shares of 1500 marks each, upon payment of 2050 marks in cash. All unexchanged shares were to be reduced in the ratio of $4: 1 .^{20}$ The resemblance to the MI.-WT. plan, which was held invalid by the Supreme Court, is striking and both follow the model

where the common stock is without par value. Sce Stone 2. Young, 210 App. Div. 303, 206 N. Y. Supp. 95 (4th Dept. 1924), and contrast Jolinson v. Lovisville Trust Co., 293 Fed. 857 (C. C. A. 6th, 1923), ccrtiorari denied 264 U. S. 585, 44 Sup. Ct. 334; see WrCkershasr, Stock witrout Par Value (1927) 81 et seq.

18 R. G. 76, 155. This case involved a limited liability company (GEsellschaft mit beschraenkter Haftung) rather than a stock corporation or Aktiengesellschaft. But the court said expressly that the principle was the same."

19 There is an excellent discussion of this reorganization by Adolf Levinger, Die Sanierung notleidender Alitimgesellsehaften (1903) 110 SCHRIFTEN DES VEREINS FUER SOZLALPOLITIK 402-418. This reorganization was unsuccessful and the company was forced to liquidate.

20 Payment might be made in bonds instead of cash, at 93 for the 4 s and $41 / 2 \mathrm{~s}$, and 100 for the $5 \mathrm{~s}$. The market prices at the time were 70 and 77. The market price of the stock was 25 . The preferred stocli was to have 6 per cent, the common 4 per cent, then both to share equally. The preferred was to be cumulative, and entitled to prior payment on liquidation. Those who thus converted their shares were also to have the right to subseribe to all the preferred shares that remained. The bondholders objected to other parts of the reorganization plan, namely, the granting of security to the bank creditors. They formed a protective committee and succeeded in getting equal terms with the banks. They also demanded that the stocls be reduced in the ratio of 5:1 and that all bond issues be accepted at the same price. 
for reorganization before 1902.21 In view of the attack on the M.-W. plan, the Helios company postponed action until after the cour't's decision. Thereafter the plan was changed so that all of the stock was first reduced in the ratio of 5:1. By paying 1000 marks in cash, and the same amount in the reduced common stock (equal to five old shares), the stockholder would receive a new preferred share of 2000 marks. ${ }^{21}$ The plan adopted by the M.-W. Bergwerksverein, after its old one was held invalid, is almost identical with that of Helios. ${ }^{22}$ And these cases have set the pattern for all subsequent reorganizations. ${ }^{23}$

In form, therefore, the change is simply one from a qualified reduction of capital stock to a combined reduction and increase. The two may be combined in one resolution and may also be effectuated simultaneously. ${ }^{24}$ It is not necessary to use new certif-

21 The preferred stock was entitled to 6 per cent cumulative dividends. Of the remaining earnings, one-fourth was to go to the preferred, and the rest divided equally according to par value between preferred and common. No bonds were to be taken in exchange, but the paying shareholders might exchange bonds in their possession for equal amounts of preferred.

$22 \mathrm{By}$ way of further illustration, one might add the reorganization of the Jacobiwerk A. G. in Meissen in 1891. Payment of 100 marks was asked of the shareholders for conversion into preferred shares (par value 300 marks). Others were reduced in the ratio of $3: 1$.

${ }^{23}$ As these two cases show, the remedy was discovered soon after the decision. The earliest application of it is said to have been in the Elberfelder Papierfabrik A. G. reorganization of 1902; see a notice in the Reichsanzeiger a few months after the decision, reprinted in PAssow, op. cit. supra note 8, at 209-210, though the name of the company is not given.

24 Vereinigte Annweiler Brauerei A. G. reorganization of 1901. The first reorganization of the Danziger Oelmuehle A. G. in 1902 was probably completed at about the time of the court decision since it is a clear violation of it. The shareholders were asked to subscribe for new preferred in the ratio of two to one, either by paying 100 marks in cash or by exchanging 3000 marks par of common stock and 500 marks in cash; remaining common was reduced in ratio of $15: 1$. Those which were not turned in were according to the provisions of the statute (Commercial Code, $\$ 290$ ) declared void and the proceeds of the sale of an equivalent amount of new shares given to the stockholders. The proceeds amounted to one-twentieth of the par value.

In the Stettin-Gristower Cementges. reorganization of 1904, the preferred were asked to pay 400 marks per share and the common 700 marks; those who paid became Preferred Lit. A; the others were reduced $5: 3$. The result was 93 common shares, 321 old preferred shares, and 808 new preferred. In the first reorganization in 1902, payment of 300 marks was asked for conversion into preferred. The figures for the second reorganization indicate that in the company's opinion the relative status had not changed in the interim. A discussion of the second reorganization will be found in the BerLINER Morgenpost for March 4, 1904. The company was unsuccessful and its assets were transferred to the Stettin-Bredower Portland Cement Co. in consideration of the assumption of a 600,000 mark mortgage and 500,000 marks in shares.

The Duetsche Seidenspinnerei A. G. in Raupenheim reorganized in 1905, 
cates for the increase; the old ones, which are handed in for the reduction, will do just as well. And in the simple case of a reduction of $2: 1$, or payment of 50 per cent, the stockholder who makes the payment may be left in undisturbed possession of his old shares, possibly with some notation to indicate that payment has been made.

The change in substance is more difficult to evaluate. Certain things are clear, namely, that a reorganization plan calling for payment of 5 per cent with a reduction of $6: 1$ for non-payers-a plan not uncommon before the decision ${ }^{25}$-is definitely banned. On the other hand, it is doubtful whether the stockholders of Helios who did not pay the assessment were much happier under the new plan than under the old. The protection afforded by the court's ratio depends entirely on the extent to which the stock of the shareholders who pay is buttressed with preferred rights. Since the preference rights are usually extensive and since they apply both to the old and the new shares of the paying shareholders, the non-payer is still at a genuine disadvantage.

The result, as here pictured, coincides substantially with that of the Boyd case. ${ }^{26}$ The latter also eliminates the extreme casethe entire exclusion of general creditors from participation in the reorganized company. But, as developments since it was decided show, ${ }^{27}$ it by no means guarantees them a substantial interest, much less the payment of their claims.

Some of the variations presented by different reorganizations can be briefly summarized. In a few instances the new shares issued were not given preferred rights, another indication of the dislike for preferred shares where they can be avoided. The Stahl and Eisenwerke Dalhausen A. G. did not offer its new shares directly to the stockholders, but indirectly through a bank; in a few other instances the new subscriptions were underwritten.

Where there is no expectation that the small stockholder will

either by reduction of $3: 2$ or payment of one-third and conversion into 6 per cent cumulative preferred. Payments were made on 1269 shares; 3 were purchased and destroyed; the remaining 1728 shares were reduced to 576. To restore the capital stock to its original figure, 1155 preferred shares were turned over to a bank consortium which offered them to the stockholders for subscription.

25 This was the resolution held invalid in the lower court opinion eited supra note 10. Theoretically a similar result can be achieved by an inordinate reduction accompanied by the issue of new shares at par to those stockholders who wish to pay the assessment. But such a course is highly inexpedient and, despite the positive assertion of its validity, may prove judicially unwise. The courts seem, however, to have allowed wide latitude to reductions. See 14 LeIPziger Zertschrift 63, and criticism in the last chapter of PINNER, BeITRAEge zuM AKTIENREchT (1918).

${ }^{26}$ Supra note 11.

27 Ibid. 
contribute his proportionate share of the new money, and occasionally for other reasons, the shares will be issued to a large stockholder or a parent corporation. ${ }^{28}$ In case this source of new money is also dry, the increased stock may be offered to an outside group, ${ }^{29}$ though this device is naturally resorted to only in extremis. In a few cases the stockholders were asked to subscribe, not for new stock, but for a bond issue, ${ }^{30}$ but this variation is much less frequent in Germany than in America.

It has happened in a number of instances that at the time of the reorganization the promoters of the enterprise were charged with having overvalued the property originally. Either because of a burdened conscience, or to avoid possible or actual litigation, the promoters have sometimes been known to place a block of shares at the disposal of the company. ${ }^{31}$ This naturally, facilitates the reorganization as it lightens the burden of the other shareholders. Where the stock is all in the hands of one group, as in the Elektrische Strassenbahn Bamberg, a surrender of some of the shares has little significance.

28 Examples are the purchase of part of the Ufa's new shares by the Deutsche Bank, and the Schoendorff family (Karstadt Konzern) purchase of part of the new shares of the Gebrueder Schoendorff A. G. in Dusseldorf.

The Ostdeutsche Stanz-und Emaillierwerke A. G. belonged to the Stinnes group. After the capital was reduced it was increased by twice the amount remaining, with a proviso that the shares not subscribed for by the old stockholders were to be put at the disposal of the Hugo Stinnes firm in Muehlheim.

After the capital stock reduction of the Siemens Elektrische Betriebe A. G. was completed, the Prussian government bought a mejority of tho shares and subscribed for a capital increase of 4 million at par. This was all the more noteworthy since the stock was then selling at 62 . The namo of the company was changed to Nordwestdeutsche Kraftwerke A.G.

${ }^{20}$ Part of the Ufa stock was thus sold. Compare also Hannoverscho Waggonfabrik A. G. and Rheinische Metallwaren u. Maschinenfabrik, infra page 766 .

${ }^{30}$ The second reorganization of the Danziger Oelmuehle was effected by means of a 1,000,000 mark bond issue (5 per cent) to stockholders at 97. Those who subscribed had their shares converted into preferred stock. The other shares were reduced to one-third. This reoganization, like the prior one of this company, raises legal doubts. See supra note 23.

The reorganization plan of the Koenigin Marienhuette A. G. in 1901 asked the shareholders (par value of share was 600 marks) to pay 100 marks per share in cash and to subscribe to the extent of 150 marks in a $41 / 2$ , per cent bond issue at 105 . The shareholders who complied had their shares converted into 5 per cent non-cumulative participating preferred; the others were reduced 2:1. A total of 8346 shares were converted; 1490 shares remained. The last quotation for the stock was about 28. The now common was introduced on the exchange at 20 , the preferred at 52 .

31 The promoters of the Deutsch-oesterreichische Mannesmannroehrenwerke promised such a surrender of stock, repudiated, and finally performed the promise with some modifications, after litigation was begun. 
The only cases that remain are those where all or part of the new stock was offered to creditors or bondholders. This leads us to the other groups of reorganization,-to those where the rights of creditors have been affected. But before passing on to these we might note the applicability of combined reduction and increase of capital stock as a device in American reorganization. The situation is aptly described in a passage in Dewing::3

"An unusual but efficient and direct plan is followed by the Massachusetts textile mills when they find their credit impaired. The stockholders first authorize the reduction of the capital stock by a certain proportion, possibly 50 per cent. This involves the cutting of each stockholder's interest in half. They then authorize the sale of the stock surrendered at par to either the old stockholders or outside bankers. The final result of these two steps is a substantial increase in the available money, without any increase whatever in either the amount of stock outstanding or the direct liabilities. This method has been applied in other reorganizations outside of New England, but in a less drastic form. Its advantages lie in its simplicity and the slight dislocation of the corporation's business which is likely to occur." 33

Why such reorganizations are unusual is not apparent; nor does Dewing offer any explanation. One may hazard a guess that our industrial companies usually allow the stage where this sort of action suffices to pass, and perhaps necessitate a receivership. With the latter, more effective means may safely be employed against the non-paying stocliholder, and there is seldom any great temptation to preserve the identity of the old corporation.

\section{EONDHOLDERS' REORGANIZATIONS}

Readjustments of bondholders' claims are almost all effected under a statute passed in 1899. This law, usually referred to as the Bond Law (Schuldverschrcibungsgcsetz), has for its full title "Law concerning the Rights in Common of Owners of

32 Deming, Financial Policy of Corporations (2d"ed. 1926) 1112-3.

33 "An excellent example of this type of reorganization possessing a more than local interest is the first reorganization of the W'cstinghousa Electric and MIanufacturing Company in 1891. The company had grown very rapidly. As a result its unsecured debt had attained threatening proportions. The management conceived the wise plan of selling preferred stock: to the creditors and outside bankers, but were unwilling to merely increase the outstanding capitalization. Accordingly, the Westinghouse Company proposed that the stockholders should surrender 40 per cent of their holdings to the company's treasury. The treasury stock thus obtained could be made preferred and sold for the benefit of the company. Great dificulty was experienced in persuading the stockholders to endure the sacrifice, although it saved the company from threatened bankruptcy." Ibid. $1118 \mathrm{n}$.

The Westinghouse Company reorganization was somewhat different from the type discussed thus far since it involved the funding of creditors' claims. 
Bonds." ${ }^{4}$ It is applicable whenever bonds of a total nominal amount of at least 300,000 marks are issued, whether secured or unsecured, whether the debtor be an individual or a group or corporation, ${ }^{35}$. so long as the bonds are all of one class, i.e., each bondholder is granted equal rights corresponding to the nominal amount of his holding.

The statute provides for meetings of the bondholders which are the basis for all further action. They are to be called at the instance of the debtor, and at his expense; but an application may be made to the court by the holders of five per cent of the outstanding bonds and the meeting called over the debtor's objections, though he has the right to be heard. The announcement of the meeting must state its objects and the reasons for calling it. By a majority vote of the amount represented a common representative of the bondholders may be appointed, and by a three-fourths vote the power of the individual bondholder to enforce the rights arising from the obligation may be cut off. Resolutions by which rights of bondholders are surrendered or restricted may be adopted only for the preservation of the common interests of the bondholders, and only to avoid the insolvency or bankruptcy of the debtor. They require a three-fourths majority of the votes cast. If the nominal amount outstanding does not exceed twelve million marks, the affirming votes must represent at least two-thirds of such amount; if there are more than twelve but less than sixteen millions outstanding, at least eight million must approve; and if sixteen millions or more, at least half. Resolutions so adopted are binding on all bondholders of that class. They must, however, predicate equal rights for all bonds; unequal treatment is permissible only with the express

34 This act went into effect December 4, 1899. It had predecessors in Austria and in' some of the German states, but apart from historical 'organization of bondholders in the earlier commercial history of Europe the chief model was the Companies Act of England. This model was greatly enlarged upon. The theoretical difference between the German and the English statutes is that the latter envisage simply a sacrifice made by creditors for the avoidance of bankruptcy, whereas the former considers the bondholders as forming an interested class or aggregate similar to stockholders, meeting, appointing representatives, and adopting resolutions for their common benefit. Such statutes play an increasingly important role in European finance, especially since the war. Two interesting volumes by Escarra, L'ORgaNisation DES OBLIGATAIRES (1922) and L'ORGaNisation LÉGALE DES PORTEURS D'OBLIGATIONS (1919), discuss the various statutes (the texts of which are all translated into French) and the precedents, beginning with the Bank of Genoa organization in the fifteenth century. The leading commentaries on the German act are by KOENIGE (2d ed. 1922), and GOPPERT (2d ed. by Trendlenburg, 1915); further literature is referred to in Koenige. See also SEeling, Die Industrie-obliantion (1919).

${ }_{35}$ With the exception of bonds issued by the Empire, a German state, or a public corporation. 
consent of the bondholders who are discriminated against. Every other agreement between the debtor or a third person and a bondholder, by which the latter is to be favored, is void. A resolution which is brought about by favoring individual bondholders is not binding on the others. The nominal capital claims of the bonds cannot be affected by resolution (e. g., the "par value" may not be reduced, nor may the bonds be converted into some kind of stock interest), nor can the bondholders be obligated to make payments of any kind.

This statute eliminates the necessity for majority provisions such as are found in Canadian mortgages ${ }^{\circ 0}$ and to an increasing extent in our own.37 As a result, the German trust indenture is an extremely short and simple affair.

In practice the procedure is to call a meeting of the bondholders in the manner prescribed by the statute. At this meeting the bondholders appoint one or more representatives. The usual choice is a trust company, which acts as the financial adviser, checks the books of the company, and the like, and individuals who are more specifically to represent the interests of the bondholders and to draw a reorganization plan. At the same time the power of the individual bondholder to enforce his claim against the company is cut off. If the danger of a default is pressing, the interest payments for the next quarter or half-year may be waived or deferred. ${ }^{38}$ A plan of reorganization is then drawn by a committee of the parties interested, and submitted at a subsequent meeting. The bondholders, if they approve the plan, will adopt it by appropriate resolutions, conditioned, perhaps, upon the due performance by the stockholders of the terms imposed upon them.

A great deal of difficulty is presented by the provision that the capital claims of the bonds must not be disturbed. This makes impossible the refunding of fixed charge securities into a preferred stock or other security of different capital nature or amount..39 As a result, other means must be employed when such

${ }^{36}$ See Fraser, Reorganization of Companies in Canada (1927) 27 Cor. L. REv. 932.

37 Almost the sole discussion of such clauses is in two notes in (1927) 27 CoL. L. REv. 443, 579.

38 Since the power of the individual bondholders is excluded, it is not obvious why this is necessary. The explanation lies in the fact that the directors of corporations are under a duty to institute bankruptey proceedings in case it appears that all of the capital is lost, or that the company is insolvent. The waiving of interest relieves the directors from this duty and keeps the company out of the bankruptey courts.

39 With the exception of income bonds-one such case is cited below. But income bonds were almost unknown in Germany before the war and are only slightly used today. Where they do appear, they provide for a fixed charge with a possible further participation. See infra note 53. 
a change is imperative. In two instances this was done success. fully. Both companies were mortgage banks, which were the heaviest sufferers in the banking catastrophe of 1901 . The Prussian Mortgage Bank (Preussische Hypotheken Aktien-Bank) 40 suffered chiefly from huge real estate speculations. Intercorporate manipulations had concealed the true state of the company until it was well on its way to ruin. It appeared that of more than 350 million marks of bonds in circulation a considerable portion was not covered by adequate mortgage security, nor could the interest required for the bonds be earned. Finally, the large Berlin banks ${ }^{41}$ decided to help in disentangling the affairs of the company, and called for deposit of the bonds. ${ }^{42}$ The deposit agreement authorized the committee to exercise the legal rights on the bonds, to close necessary contracts and transact necessary business, to advance interest on the next two coupons, to represent the bonds in bankruptcy if necessary, to conclude compromises, to participate in execution and foreclosure sales, and to take measures to limit the rights of the bondholders or to substitute a new debtor. A general meeting of certificate holders was to pass upon all measures involving surrender of rights, by majority vote. The dissolution of the organization could take place only at a meeting where one-half of the nominal amount deposited was represented and only by resolution of three-fourths of the amount voting.43

A bondholders' meeting was held on Dec. 31, 1900 at which 305.5 of a total of 357.6 millions were represented (of which 290 had been deposited). Resolutions were adopted to pass the Janu-

${ }^{40}$ An excellent discussion of the reorganizations of the Preussiche Hypotheken Aktienbank and the Pommersche Hypotheken Aktienbank by Ernst Kritzler was published in (1903) 111 SchrIFTEN DES Vereins FUER SoziatPOLITIK 3 et seq. Information for later years can be obtained in the annual volumes of Saling's BOERSENPAPIERE and the HANDBUCH DER DEUTSCHEN AmTIENGESELLSChafteN. In discussing the reorganization of these two banks the facts have been simplified, and the disentanglement of the relations of the banks in question with their affiliated companies left entirely out of account.

$41 \mathrm{~A}$ number of the large mortgage banks, fearing the effect of a reorganization on the market price of their own bonds, had offered to advance 15 millions if the affairs of the Preussenbank could thereby be disentangled. It soon appeared, however, that the damage was worse than was estimated, and the offer was withdrawn.

42 Deposits of bonds, or of any securities for that matter, are comparatively rare. Such deposits were made by the Helios bondholders. Seo supra note 20 . Occasionally stockholders have formed deposit committees for protection of some common interests. See PASSOW, op. cit. supra noto 8 , at 160 et seq. In the famous case of the Hibernia mine they formed a new corporation whose assets were the deposited shares.

43 An additional reason for advancing the interest was that the company would have had to go into bankruptcy if the bondholders did not waivo tho interest payment, and it was doubtful whether this could be dono in timo. 
ary and April interest (the two payments which the banks were authorized to advance), to let the Deutsche Treuhand Gesellschaft enforce the rights of the bondholders, and to exclude the power of the individual bondholders to bring suit against the company.

For the reorganization the following things had to be borne in mind:

1. 17.5 million marks had to be supplied in cash in order to replenish the reserve fund required by the mortgage bank-law.

2. The two interest payments had to be provided for.

3. A stock capital equal to one-twentieth of the bonds in circulation had to be provided for, as required by statute.

Two plans were proposed. The first involved reducing the interest for the next ten years on the bonds by one-fifth; passing the next two interest payments entirely, and issuing stock for the subsequent eight interest payments (two years). At the same time the old capital stock was to be cut to one-tenth, to go to the old shareholders to secure their cooperation.

The alternative plan was first to reduce the stock in the same way but then to increase it by an amount equal to 15 per cent of the bonds. The new stock was to be offered to bondholders in exchange for the surrender of 20 per cent of their bonds, the interest on the remaining bonds to be paid in full. This plan was considered more advantageous both for the bondholders and for the company, but could not be imposed by a statutory proceeding since it involved reducing the nominal amount of the bonds. Hence the first plan was approved at a new statutory meeting. The certificate holders then met and unanimously adopted the second plan with certain conditions. The stockholders agreed, and all but about seven millions of the bonds were in fact refunded under the second plan.

The other case where the bondholders were induced to cut down the amount of the bonds is that of the Pommersche Hypotheken Aktienbank, another mortgage bank which was in diffculties at the same period. The bondholders' meeting took place without any prior deposits, which may account for the fact that the ultimate participation in the capital surrender was not as great as that in the Preussenbank. With a view to further adjustment the bondholders agreed to reduce the next half-year's interest and appointed the Darmstaedter Bank to draw a reorganization plan. The following alternative proposals were made: either a surrender of one-fourth of the interest permanently with no interest whatever for about four years (for which interest payments stock was to be issued) ; or the surrender of one-

14 See Hecht, Die Devitsche Treuhand Gesellschaft (1903) 111 Scuniresi DES VEREINS FUER SOZLAIPOLITIK 103, for the early history of this company. 
fifth of the capital amount of the bonds in exchange for stock for half that sum. The latter would enable the company to set up a reserve and in the event of success the amount thus surrendered was to be paid to the bondholders. The first proposal was accepted with practical unanimity at the meeting that was called to pass upon it, and then about three-fourths of the bondholders individually accepted the alternative.

These two exceptional instances ${ }^{45}$ indicate the procedure by which bond principal may be cut down or converted in a reorganization. The usual terms involve the passing of interest payments immediately due, ${ }^{46}$ a permanent reduction of interest, ${ }^{47}$ and often a change in the amortization plan. ${ }^{48}$ For the purposes of the reorganization part or all of the lien may be surrendered, ${ }^{40}$ the maturity of the loan may be changed, ${ }^{50}$ or a loan which is due compulsorily refunded.51 Occasionally, unsecured bondholders succeed in getting a mortgage security in exchange for the sacrifices they make.52 In a few instances the reduction of interest was coupled with an agreement to pay greater interest if earned, ${ }^{53}$ almost the only examples of income bonds which existed before the war in Germany.

A special difficulty arises in the application of the Act because of the fact that if part of the bonds are due, either on account of varying maturities or because bonds have been called for redemption, such bonds are classified separately and must be treated accordingly. Hence, if these bonds should not total 300,000 marks, the statute is not applicable to them and concerted action with regard to them is impossible. Even if they total the required sum, their holders are comparatively more scattered and it is difficult to get a sufficient amount represented at the meeting. It is usual in practice to grant such bonds preferential

45 Compare the Deutsche Grundschuld Bank reorganization, infra page 768.

46 Blech u. Emaillierwerke; Siemens Elektrische Betriebe.

47 Pommersche Hypotheken Aktienbank; Preussische Hypotheken Aktienbank; Aktienbrauerei Goblis in Leipzig.

${ }^{48}$ Blech u. Emaillierwerke; Siemens Elektrische Betriebe.

40 This happens with great frequency; the trust indentures usually authorize the trustee to release the security or part of it upon substitution of securities of equal value, but this is inadequate to meet reorganization needs.

50 This is always involved when the amortization plan is changed, but sometimes the change is more radical, e.g., the treatment of the Siemens Elektrische Betriebe bonds which had been called for redemption. See infra note 51.

51 For example, in the reorganization of Siemens Elektrische Betriebo there were many bonds called for redemption and therefore due. It was agreed to pay these bonds in five installments. This was done by majority vote, and was therefore binding on all.

52 E.g., Helios reorganization.

53 Mecklenburg-Strelitzsche Hypothekenbank; and see supra noto 39. 
treatment in the reorganization plan, although it is hard to determine whether this is a recognition of an equitable claim, or a bargain with a relatively unimportant group.

It would seem that the major difficulty, a reduction of the capital amount of the bonds, might easily be overcome by an appropriate provision in the trust agreement, such as is found in English and Canadian issues and to an increasing extent in our own. This seems never to have been attempted. The reasons are largely that before the war the country enjoyed a wave of prosperity and such difficulties were not envisaged. Nor were German lawyer's sufficiently familiar with such provisions in other countries to be ready for the innovation. ${ }^{55}$ Finally, it must be remembered that the German trust indenture is a short typewritten document in which nothing but bare essentials appear, and the insertion of such a revolutionary provision would have had unwelcome prominence. The danger of unusual clauses is especially important since the war, where the competition for capital investment is excessive, and their introduction might impair the saleability of the bonds.

German writers are by no means agreed that the effect of this statute has been uniformly for good. The general consensus is clearly that the statute itself is desirable, and the immediate application of it shortly after its passage in the mortgage bank instances showed the decided advantage of the presence of such a statute even where it was necessary to secure deposits of the bonds to accomplish the desired reorganization. But the remarli of the editor of Saling's Boersenpapiere holds good:

"Despite the precautions offered by the statute it is by no means certain that bondholders' meetings adopt resolutions which in fact correspond with the interests of the bonds. Rather it is conceivable that with a severe market depression bonds are bought up by other interests and used for improperly influencing the bondholders' meeting." 50

This is somewhat vague; specifically, it means that interests close to the company might buy these bonds and exert pressure at the meeting.

\section{CREDITORS' REORGANIZATIONS}

Before the war, reorganizations in which sacrifices were made by general creditors were very scarce. And many of the excep-

54 Compare Siemens Elektrische Betriebe, discussed supra. notes 50 and 51.

55 The only variation from the norm that the writer has been able to discover in these indentures is a waiver by the bondholders of their statutory right to security (Commercial Code, $\$ 289$ ) in case the capital stocl: is reduced.

56 1 Saling, Boersenpapiere (1926) 87. 
tions turn out upon examination to have special reasons. Such was the surrender of part of its claim against the Elektrische Strassenbahn Bamberg by the Commerz u. Disconto Bank, ${ }^{b r}$ since the total share capital of the former was in the hands of a consortium led by the latter. Such was the action of the Deutsche Bank concerning the Ufa after the war. ${ }^{58}$ Similar reasons probably account for the surrender of bank claims aggregating two million marks against the Gewerkschaft Huesten, though how the banks were compensated is not clear.

The fact is that the treatment of unsecured creditors has been the sore point in German reorganization. With perfectly feasible methods of dealing with stocks and bonds, and with little criticism of the provisions made for stocks and bonds in reorganization plans, by either the courts or the press, the absence of a method for dealing with unsecured creditors produces a curious anomaly. Institution by the legislature of some device for binding general creditors by majority agreement was proposed time and again and always without success..$^{60}$ This accounts largely for the scarcity of instances before the war in which sacrifices were asked of general creditors. In fact, they have in some cases been treated better than the bondholders, although, if the company had been liquidated or put into bankruptcy, these general creditors would have fared very badly. In the reorganization of the Mecklenburg-Strelitzsche Mortgage Bank there were four and a half millions of unsecured creditors' claims as against twenty-five millions of mortgage bonds. The total number of creditors was too great for any attempt to gather them together and coerce them into some sort of agreement with the threat of bankruptcy, and the amount involved in paying them in full was too large a sacrifice to be faced with equanimity. For some time this impasse continued, the bondholders making necessary sacrifices to avoid bankruptcy and the company trying to straighten out its affairs. But it seems that the bonds yielded in the end and the unsecured creditors were paid in full.

Since 1914, however, conditions have been considerably altered. A half-century's agitation had failed to impress the government that there was need for a proceeding for settling with general creditors without resorting to bankruptcy. But the war made short work of this resistance, and in 1914 a brief

57 See HANDBUCH DER DEUTSCHEN AKTIENgesellschafTeN for 1907-8.

58 The reorganization of the Ufa aroused nation-wide interest. Discussions of it may be found in many issues of standard journals, such as the MAGAZIN DER WIRTSCHAFT and DeR DEUTSChe VolKsWIRT during 1927, as well as the business pages of the newspapers.

59 For a brief history of these attempts see the introduction to Dr. Kiesow's commentary on the GESET⿰亻 UEBER DEN VERGLEICH zUR ABWENDUNG DES KONKURSES (1927). 
act ${ }^{60}$ was passed providing for receivership for the avoidance of bankruptcy. The official justification was the necessity of continued production, even at the cost of malking the strong enterprise support the weak. The receiver, who was appointed by the court, might be endowed by it with considerable power over the conduct of the debtor; otherwise everything continued as before, with the exception that creditors were compelled to wait until the debtor was in a position to pay. No terminus for the receivership was set, nor was any foreseen other than the end of the war.

Despite the anticipated repeal when peace should be restored, the act retained its form, with minor changes, ${ }^{02}$ for nine years. This was due in large measure to the curative effect of inflation, which removed insolvency without any effort of the debtor. But in February, 1924,62 a limit of one year was set upon the length of a receivership, among other amendments; and in June, 192., ${ }^{, 3}$ further changes were made. These show a considerably altered viewpoint. Whereas in the earlier legislation it was considered of the utmost importance to limit public knowledge of the fact of receivership, the new order provides for publishing the granting and the ending of the receivership as well as the name of the receiver. An expert or a government body must be consulted about the advisability of the receivership. A creditor's' committee, with definite powers, must be appointed. The length of the receivership was again shortened.

Even in this guise the business world persisted in regarding this act as war legislation, to be supplanted as soon as the weightier affairs of the post-war readjustment were taken care of. But it is interesting to note the different character of the reorganizations that took place during this period. Although the time for its application was comparatively short, we have in this period a number of instances of sacrifices made by creditors in the course of reorganization. A proposal made by the Mauls Kakao u. Schokoladenfabrik to reduce its paper mark capital of 63 million to three million, of which five-sixths was to go to creditors in satisfaction of claims (par value stock for $80 \%$ of the face amount of the claims), the small creditors being paid in cash, was objected to both by the creditors' committee and by the press. The latter insisted that unless creditors are paid in

${ }^{60}$ Anordnung einer Geschaeftsaufsicht aur Abucndung des Inonlourses, REICHSGESETZBLATT (1914) 327 et scq.

61 Verordnung des Bundesrats uber die Geschaeftsaufsicht aur Abucndung des Konkurses, ReICHSGesetzblatT (1916) 1363 et seq. The text as amended in 1924 is reprinted in 107 Sadranung Deutscher Gesetze. Sez Gaten, GeschaefTsaufsicht und ZWangsvergleicir (1917) and SuppleMENT (1924); JAEGER, DIE GeschaEFTSAUfSicht NeUER ORoNusg (1917).

62 1 REICHSGESETZBLATT (1924) 51 et seq.

63 Ibid. 641 et seq. 
full stockholders should receive nothing. But the company was in receivership so that by the terms of the statute the creditor's could not even force liquidation, and hence they were compelled to accept these terms. This was especially severe, not only in that the claims were funded, but that a part of them was surrendered entirely.

Almost the same situation was present in the case of the Mollwerken A. G. in Chemnitz, in the business of auto manufacture and metal work, with the exception that here the creditors were given 70 per cent of their claims in 8 per cent preferred stock. In these two cases, however, the stockholders won Pyrrhic victories since both companies became bankrupt in a short time. In the A. G. Neptunschiffwerft $u$. Maschinenfabrik the impression is created that creditors were equally hard-hit, since the capital of 500,000 was reduced to 100,000 and then increased by $1,900,000$ to take care of the unsecured debts. But here there were only two large creditors so that in effect the sop of 100,000 thrown to the old stockholders was merely a slight payment for complacence in the readjustment. Any other legal device for getting rid of them would have cost much more. But the Aquila A.G. reorganization belongs with Mauls Kakao and Mollwerken except that here the creditors received their 70 per cent in cash. Much more complex than any of these was the readjustment of the Hannoversche Waggonfabrik A.G. A considerable amount of surplus land was sold to the city of Hannover; some shares in the company were sold to another Hannover company; a debt secured by mortgage and held in Holland was renewed. A large claim by a Hannover bank was settled by transferring to the bank the company's claim against the government for war reparations. After a stock reduction new stock was issued to the unsecured creditors, including part of the bank claims. The remainder of the bank claims were extended and secured by the entry of a second mortgage. The government was induced to waive part of the unpaid taxes and extend the time of the rest. The result was to provide enough money for preferred claims and leave some working capital.

It is, of course, difficult to say that the reorganizations of post-war Germany offer a parallel to the pre-war cases. It may be that the losses were more severe and that the sacrifices creditors were called upon to make in the later reorganizations would simply have meant bankruptcy in the earlier days when the persuasive force of the receivership was lacking. And the fact that two of these companies did go into bankruptcy shortly afterward would indicate that the little reserved by the stockholders was worth even less. It is not a question of the merit of the general creditors' claims, since sometimes they have a tactical advantage 
over mortgage bonds, but of the difference which legal machinery makes upon the course of reorganization.

Of course there are cases, and they are well known in this country, where the creditors have been forced to accept sacrifices which went to the partial advantage of stockholders, and which were unjustified. That this has been to some extent the situation in Germany is attested by the constant criticism to which the receivership act was subjected, and by its recent change. The new act, which went into effect in July, 1927, cs differs widely from its predecessors. Instead of being a lax device by means of which a declining business might put its creditors at bay, it aims to be the minimum possible concession to a worthy but unfortunate debtor. The application for receivership must be accompanied by a scheme of settlement with creditors, which must already have been assented to by the majority of them. If the proposal is for a cash settlement, not less than thirty per cent must be offered. If the application should be denied or the receivership terminated by the court for cause, or for failure to get the required majority of creditors in favor of the compromise, the court must regard the application for receivership as automatically converted into one for banliruptey. These novel provisions are due in part to new sentiments; there was a feeling that reorganization as distinct from liquidation helped to maintain prices, and was in some instances not to the interest of the public, ${ }^{, 5}$ even though the individual debtor and

64 Gesetz ueber den Vergleich zur Abwcndung des Konlunrscs, 1 ReIchsGESETZBLATT (1927) 139 et seq.

65 This criticism of the effect of reorganization is based solely on ehortterm tendencies and the fact that a receivership keeps a stock of goods, which would otherwise be sacrificed, from being thrown on the market. In this form the criticism may be conceded. The long-term tendency of reorganization on price structure is something that we at present lnow very little about. A first reaction might be that rearganization, by maintaining a competitor in the industry, increased the volume of production and helped to lower prices. This reaction may, however, be false; at least two things to the contrary suggest themselves. The first is that a reorganized company is likely to write down its assets to an extremely low figure and thereby show an apparently small overhead cost for the future. This may have the effect of producing excessive competition and eventual disruption of the market, with a later return to a higher price level when the weaker competitors depart from the field. The period of disruption, whatever the ultimate effect on prices, is deplorable. The second suggestion is based on a supposed tendency of prices to become more or less stratificd at a level just sufficient for the intra-marginal producer. If he should be removed in those cases where he falls below the margin, the stimulus to competition produced by a drive for his old customers may cause fluctuation and increased production on the part of more favorably situated enterprises, which eventually result in a lower price level. The last point to be considered is the possibility that the continued presence of the morginal producer tends to make the total supply so large and the outlook 
his creditors might fare better than in liquidation or bankruptcy. This was quite apart from the feeling that creditor's were often injured; the fact is that from 1919 to 1924 the number of companies in receivership was only slightly behind the number in bankruptcy, and in 1924, the most difficult year of all, the new receiverships actually surpassed the cases where bankruptcy proceedings were instituted.

That this statute will diminish appreciably the number of companies applying for receivership is probable. Whether it will materially restore the situation before the war, and make a creditors' reorganization almost impossible, is not clear. There is a provision in the act which invalidates executions made within thirty days of the opening of the receivership. This may prove to be a powerful weapon in persuading creditors who have not been fortunate enough to seize part of the property to consent to the receivership application. Some of the provisions may, however, turn out to be unwise; for example, the requirement of thirty per cent if a cash settlement is offered can be easily evaded if another form of settlement is proposed, and may work to the disadvantage of creditors who wish to avoid bankruptcy but see no possibility of securing thirty per cent in cash.

\section{INVOLUNTARY REORGANIZATION}

The type of reorganization most familiar in America, one which includes receiverships, judicial sales, and upset prices, is almost unknown in Germany, as is sufficiently evident from the foregoing. The few exceptions arise out of bankruptcy proceedings. For reasons similar to those which make reorganization through our bankruptcy courts comparatively undesirable, 0 sale or liquidation is the more likely procedure. In the exceptional case it may happen that a banking group interested in the property will come forward and strive to make some arrangement.

The only instance of this kind that deserves mention is that of the Deutsche Grundschuld Bank. This company was a subsidiary of the Prussian Mortgage Bank and was formed chiefly for the purpose of taking over the more dubious investments of the latter. It was naturally in worse straits when the crnsh came. Since no arrangements to avoid bankruptcy were possible, the company was declared bankrupt. The disentanglement of its

for a newcomer so poor that the opening of new enterprises in the particular industry is discouraged. Unfortunately, no detailed consideration of any of the foregoing is yet to be had though HAmiLTON AND WRIGHT, The CASE of BITUminous CoAL (1927) 155, 187-8, have some comment and VEBLEN, ABSENTEE OWNERSHIP (1923), suggests a general approach.

o6 See Cravath, Reorganization of Corporations, in Some Legax Phases of Corporate Financing, Reorganization and Regulation (1917) 160-1. 
affairs required, however, far more time than could possibly be granted under the bankruptcy statute; and some bankruptcy law requirements ${ }^{67}$ were practically out of the question without ruinous sacrifices. This led the banking group to obtain deposits of the greater portion of the bonds. The banks bought the property from the trustee at the price which in the latter's opinion could be realized by slow liquidation. ${ }^{\text {ss }}$ The bondholders were given the choice of taking new securities or their distributive share of the sale price. Most of them chose the former, and the reorganization ultimately turned out to be more simple than the state of the company and the novelty of the procedure would have led one to predict.

Such procedure is, however, extremely rare. The more common cases are hardly reorganizations in the sense with which we are familiar. For example, the bondholders of one enterprise ${ }^{69}$ voted to purchase the property at the foreclosure sale, to pay dissenting bondholders their distributive share of the purchase price, and to hold the property until it could be disposed of. This hardly suggests the pattern of reorganization, since the measures envisage ultimate liquidation of the interests of the old security-holders and the object is simply to postpone the liquidation to a more favorable date.

Reorganization by meeting and resolution is therefore almost as widespread in Germany as it is in England. The only exception is in the treatment of general creditors, where the procedure is correspondingly complicated. In a number of obvious respects this simplicity is distinctly advantageous as compared with the more elaborate routine in American reorganizations, especially those of railroads. There are, however, drawbacks to which one may well call attention because of their home moral. The first and most important is that the practice of reorganization without the aid of the court leaves the outvoted party without practical

${ }^{67}$ Such as sale entirely for cash, extremely difficult with real estate.

68 The trustee counted on realizing 40 per cent if 5 years were allowed. Total debts amounted to 97.6 millions, which malkes practically the 37.94 bid by the committee.

69 This instance happens to involve a shipbuilding ${ }_{c}$ company. Examples are very hard to find since they achieve little publicity and must be gathered from the recollection of business men and lawyers.

A somewhat similar case was the foreclosure of the Ver. Dampiziegeleien mortgage. Bonds amounting to 840,000 marks were transferred to a banl: consortium which in turn created a new company to hold the bonds. The other bondholders were offered 15 per cent in cash by the banlis. The new company bid in the property at a very low figure, but the sale was held invalid by the court on account of the inadequacy of the price. See article by Landesmann in DIE BANK (1916) 485 et seq. For a discussion of the law relating to; inadequacy of price in foreclosure sales in Germany and its lack of efficacy, see Nussbaun, Die ZwaNGstersteigerung (1916), and compare Weiner, op. cit. supra note 11, at 133 et scq. 
opportunity to have the fairness of the plan tested by a court, the only apparently impartial arbiter provided by our legal and industrial system. This defect has been met in England by requiring the approval of a court to a plan of reorganization before it can be put into effect. Judicial approval is required by our more cumbersome procedure, especially in its recent developments. But neither the German procedure nor reorganization under majority clauses in trust indentures provide an adequate substitute. That independent collateral attack by a bill for injunction or the like affords such a substitute will hardly be maintained.

Another major drawback lies, paradoxically, in the very ease with which reorganization can be effected. Perhaps the most valid defence of the American procedure is that its delay enables the facts of the failure and the possibilities for the future to be thoroughly canvassed. It enables the plan of reorganization to be thrashed out, with regard both to adequacy and fairness. There is little excuse for requiring creditors to make sacrifices if the enterprise is to go bankrupt shortly afterward. And the number of instances of recurrent failure, some with ultimate liquidation, which appear in the history of German reorganization, are a by-product of simplicity that is deplorable from any point of view.

\section{MISCELLANEOUS PROBLEMS}

Like all bas-reliefs, our outline has failed to give a full picture of the process of change represented by reorganization. Much space could be devoted to the conversion of an ambitious and far-flung enterprise into one of humbler mould. Thus the Ufa, the great German motion picture company, was forced to sell its chain of splendid theatres (especially the Vaterlandpalast and the Gloriapalast in Berlin), and devote itself solely to producing..$^{70}$ Many others have paid the same penalty for ambition, and have been compelled to drop appendages more or less vital to the main enterprise. ${ }^{71}$ Still others have had to release prized

\footnotetext{
${ }^{70}$ Besides supplying new money the sales helped the reorganization materially in that the former was sold for a book gain of $31 / 2$ million marks, the latter for a gain of $11 / 2$ million.

71 The Hannoversche Waggonfabrik, discussed supra page 766. One of the most notable reorganizations before the war was that of the Gowerkschaft Huesten. Just prior to the first reorganization, this company was com. pelled to lease its chemical plant, though it was part of the contemplated program of manufacture of the company. A somewhat different pressuro existed in the case of the Bergwerkgesellschaft von Giesches Erben. This more than two hundred year old company owned coal, zinc, and lead mines in Silesia and elsewhere. Many of these holdings fell in Polish territory by the peace treaty, with the result that enormous pre-war profits disappeared. New money was advanced by the Harriman group and by a German bank, the Preussag. The Anaconda Company offered to reorganize
} 
blocks of securities, carrying perhaps important advantages in integration. ${ }^{22}$ Most dramatic of all are those cases where the original controlling group sees the management pass into other hands. ${ }^{23}$ This may happen even to powerful interests if caught in a time of storm and stress. ${ }^{74}$

Another chapter in reorganization might be written about those companies whose history terminates more or less ingloriously, by fusion with a more durable friend or competitor. The unfortunate Dortmunder Union fuer Bergbau was founded in 1872 by a powerful consortium led by the Discanto Gesellschaft. After an eventful history which included several reorganizations and a sale of one of its mines, it was finally merged in 1910 with Deutsch-Luxembourg (now the United Steel Works). Similarly, the Vereinigte Annweiler A. G., whose stock was closely held, reduced its preferred to eight shares and its common to five shares, to be exchanged for a like amount with the merg. ing company. Other instances, large and small, might be added. Finally, there is a type of reorganization not often met with in this country, that of the affiliated group or Konzem. The great crop of examples here is also post-war, a period which saw the rout of perhaps the most famous of them, the Stinnes Konzern. The outcome varies from almost complete liquidation, such as befell the Stinnes interests, to partial realignments and reorganization of the individual units which compose the Konzern.

\section{REORGANIZATION SINCE THE WAR}

It may prove useful to characterize the trend of reorganization in Germany today. We have had occasion to refer to sorne of the

the Polish mines with preferred and common for Giesche and a majority of the common for Anaconda; also to advance 50 millions to Giesche for settling its German affairs. Despite the opposition to letting these valuable mines fall under the control of another country, it was conceded that American interests would fare better in Poland than German. The final clause in the agreement, that Giesche must for 25 years sell to Anaconda the zinc products from hitherto unopened fields, aroused more opposition. But the agreement was adopted. See WIrTSCHAFTSDIENST (1925) 1759.

72 This happens most often in the case of the Fonzcrn, discused below. The sale of the Baroper Walzwerk shares by the Stinnes interests led to a rescission of the contract between this company and the Stinnes Eisen A. $\mathbf{G}$. The Gelsenkirchner A. G. of the Stumm Konzern sold all its outside holdings.

73 The change in management is not always apparent, since the required publicity merely indicates that new shares are issued with the stocliholders' preemptive rights excluded. But the tongues of the market-place and of the financial journals wag.

74 In the reorganization of Rheinmetall in 1925 , Krupp, the former majority owner of the stock, was unable to advance the new money, and therefore lost his position. Otto Wolf, and A.E.G.-Linke-Hofmann-Lauchhammer, who were heavily interested, went the same way. As a result, the Interessengemeinschaft (community of interest) with Krupp was dis- 
changes. An outstanding factor was the introduction of receivership and of devices for control of general creditors by majority vote. This has been appreciably limited in the act of 1927 , but during the regime of the former act a conspicuous change was visible. Nor is it at all clear that the new law will not prove almost as feasible for reorganization as its predecessor.

Another change which can be readily earmarked is the reorganization of the Konzern. This flower of war and inflation by no means disappeared with stabilization. On the contrary, it is one of the characteristics of the present organization of German industry, and seems destined for an important role in the ern which is already beginning to be called Spätlaapitalismus. The introduction of management shares, multiple voting shares, and the like considerably strengthens its future. But some of the unhealthiest blooms have paid the penalty of too-rapid expansion, and others are almost certain to follow.

By and large, however, the most significant change lies not in these. Reorganizations in post-war Germany have been far more frequent than promotions. And yet in the constant variety thus presented, the outstanding characteristic is the effect upon the small stockholder. With almost no exceptions the small stockholder has not come forward with the new money necessary to retain his old footing in the corporation. In many cases the opportunity to do so has not been offered him. This exclusion is not wilful. The dearth of capital that is perhaps the most prominent feature of recent German finance has contributed this by-product to reorganization. The small stockholder lost what remained to him after the war in the inflation period; with it he lost also, what is equally important, a good part of that cautious enterprise and careful saving that are the backbone of small shareholding. Reorganization, therefore, has called loudly upon the management groups and their friends, the bankers, to produce the new money. After their willingness and ability were exhausted, the burden fell, especially with the availability of receivership, on creditors and bondholders. Nor was the large shareholder always immune, as some of our examples indicate, but himself surrendered perhaps a dominant position in favor of some other group fortunate enough to be able to supply cash or credit. However, despite the numerous instances of this kind, the fate of the small shareholder is still the dominant characteristic. In all cases he has been forced to recede, in many of them "beyond the horizon." The effect which such losses have had upon the distribution of corporate ownership throughout the country can only be conjectured. The fact of such losses is, however, interesting as a further illustration of the importance of reorganization in the capital structure of society.

solved and Rheinmetall abandoned locomotive manufacture. See WIRTSCHAFTSDIENST (1925) 1757 et seq. 